\title{
PARTISIPASI PUBLIK DAN KETERBUKAAN INFORMASI DALAM PENYUSUNAN KEBIJAKAN
}

(Studi Kasus Dewan Perwakilan Rakyat Kabupaten Aceh Selatan)

\author{
Ida Rahma
}

\author{
Alumni S2 Magister Ilmu Hukum Universitas Syiah Kualah \\ Dosen Pada Prodi Hukum Ekonomi Syariah STAIN Teungku Dirundeng Meulaboh \\ rahmaida1984@gmail.com
}

\begin{abstract}
Public participation can be understood as activities undertaken to memmengaruhi public policy formation process. Public participation is important to ensure that any policy that produced not only benefit certain people, but also a positive impact on society. The process can be performed through the stages of agenda setting, policy formulation and implementation. This paper is about to describe the transformation of society prevailing in Aceh after the peace agreement. Review of the literature of choice in this paper, which is supported by a wide range of documents related to public participation, freedom of public information, and peace building. The results of this study indicate that public participation in policy formation in Aceh have ups and downs. Postsignatories to the peace agreement, the level of public participation is very good especially in the establishment of the Law on Governing Aceh and Qanun Aceh. Next, in 2009-2014 public participation in policy formation decreased. Furthermore, the level of public participation in policy formation is determined by freedom of public information.

Keywords: public participation, Policy Formulation, Freedom of Public Information.
\end{abstract}

\begin{abstract}
Abstrak, Partisipasi publik dapat dipahami sebagai kegiatan yang dilakukan untuk memmengaruhi proses pembentukan kebijakan publik. Partisipasi publik penting untuk memastikan bahwa setiap kebijakan yang dihasilkan tidak hanya bermanfaat bagi orang-orang tertentu, tetapi juga dampak positif bagi masyarakat. Prosesnya dapat dilakukan melalui tahapan penetapan agenda, perumusan kebijakan, dan implementasi. Makalah ini akan menjelaskan transformasi masyarakat yang berlaku di Aceh setelah perjanjian damai. Tinjauan literatur pilihan dalam makalah ini, yang didukung oleh berbagai dokumen yang terkait dengan partisipasi publik, kebebasan informasi publik, dan pembangunan perdamaian. Hasil penelitian ini menunjukkan bahwa partisipasi publik dalam pembentukan kebijakan di Aceh mengalami pasang surut. Setelah penandatanganan perjanjian damai, tingkat partisipasi publik sangat baik terutama dalam pembentukan UndangUndang tentang Pemerintahan Aceh dan Qanun Aceh. Selanjutnya, pada 2009-2014 partisipasi publik dalam pembentukan kebijakan menurun. Tingkat partisipasi publik dalam pembentukan kebijakan ditentukan oleh kebebasan informasi public.

Kata Kunci: partisipasi publik, Perumusan Kebijakan, Kebebasan Informasi Publik.
\end{abstract}

\section{Pendahuluan}

Aceh dengan segala keistimewaan yang dimilikinya dengan lahirnya Undangundang Nomor 11 Tahun 2006 tentang Pemerintahan Aceh/ UUPA (selanjutnya disebut UUPA) memiliki ruang pelibatan dan keterlibatan publik/ masyarakat dalam penyusunan kebijakan Peraturan Daerah/ Perda (di Aceh disebut Qanun), yang kemudian dituangkan secara spesifik kedalam Qanun Nomor 3 Tahun 2007 tentang Tata Cara Pembentukan Qanun (selanjutnya mengalami revisi dengan lahirnya Qanun Nomor 5 Tahun 2011 tentang Tata Cara Pembentukan Qanun).

Perubahan sosial terus berlangsung di Aceh, pasca bencana tsunami dan kesepakatan damai. Perubahan dimaksud setidaknya dapat dibagi 2 (dua) bagian. 
Pertama, berkenaan dengan keterbukaan akses, dari wilayah yang tertutup pada masa konflik menjadi wilayah terbuka pasca bencana dan kesepakatan damai antara GAM dan Pemerintah RI. Kedua, pembentukan Undang-undang Nomor 11 Tahun 2006 tentang Pemerintahan Aceh (UU PA) pada 1 Agustus 2006. Selain mengatur pembagian kewenangan serta kekhususan lainnya, UU ini juga menjamin partisipasi publik (masyarakat/warganegara) dalam perencanaan pembangunan, tata ruang, pendidikan, ekonomi, kesehatan serta bidang sosial. ${ }^{1}$

Partisipasi masyarakat dalam pembangunan merupakan salah satu syarat mutlak dalam era reformasi ini. Pengabaian terhadap faktor ini telah menyebabkan terjadinya deviasi yang cukup signifikan terhadap tujuan pembangunan itu sendiri yaitu keseluruhan upaya peningkatan kesejahteraan masyarakat. Untuk itulah pelibatan dalam proses legislasi atau penyusunan produk hukum wajib terjadinya pelibatan masyarakat di dalamnya. $^{2}$

Proses pelibatan partisipasi masyarakat dalam implementasi program Legislasi Daerah terbukti telah berhasil membawa perubahan mendasar dalam peningkatan kesadaran hukum masyarakat. Pembangunan hukum lebih berorientasi pada masyarakat, yang tercermin melalui pengoptimalan keterlibatan masyarakat dalam rangkaian penyusunan Peraturan Daerah, di Aceh di kenal dengan Qanun. Ini perlu diyakini oleh aparatur Pemerintah baik Provinsi maupun Kabupaten/Kota sebagai strategi yang tepat untuk menggalang militansi kesadaran masyarakat terhadap ketaatan pelaksanaan ketentuan-ketentuan hukum.

Selanjutnya, pada 30 April 2008, Pemerintah dan DPR RI membentuk Undangundang Nomor 14 Tahun 2008 tentang Keterbukaan Informasi Publik (UU KIP). UU ini memberi jaminan tentang hak atas informasi publik. Hak atas informasi menjadi sangat penting untuk memastikan penyelenggaraan negara yang dapat dipertanggungjawabkan. Selain itu, UU ini bertujuan menjamin hak warganegara untuk mengetahui rencana pembuatan kebijakan publik, program kebijakan publik, dan proses pengambilan keputusan publik, serta alasan pengambilan suatu keputusan publik, mendorong partisipasi publik dalam proses pengambilan kebijakan publik, serta meningkatkan peran aktif masyarakat dalam pengambilan kebijakan publik dan pengelolaan Badan Publik yang baik.

Namun, hingga penghujung 2015, masih terdapat Badan Publik di Aceh yang belum mematuhi ketentuan UU KIP sesuai ketentuan yang berlaku. Pertanyaannya, apakah jaminan partisipasi publik sudah berlaku efektif dan sesuai harapan publik? Mengingat partisipasi publik tidak hanya dijamin melalui kebijakan, tetapi memerlukan dukungan program, anggaran, serta peningkatan kapasitas sumberdaya manusia, baik yang aktif dalam organisasi maupun secara individu. ${ }^{3}$

\footnotetext{
${ }^{1}$ Zaki Ulya, Refleksi Memorandum of Understanding (MoU) Helsinki Dalam Kaitan Makna Otonomi Khusus Di Aceh, Jurnal Konstitusi, Vol. 11, No. 2, 2014, hlm. 371

${ }^{2}$ Muhammad Siddiq Armia, Eksekutif Review Terhadap Perda Retribusi Di Daerah Otonomi Khusus, Jurnal Rechtsvinding - Media Pembinaan Hukum Nasional, Vol. 5, No. 2, 2016, hlm. 247

3 Anonimous, Laporan Evaluasi Badan Publik Tahun 2015: Laporan Evaluasi Implementasi Keterbukaan Informasi Publik pada Satuan Kerja Perangkat Aceh, Pemerintah Kabupaten/Kota,
} 
Proses pelibatan partisipasi masyarakat dalam implementasi program Legislasi Daerah terbukti telah berhasil membawa perubahan mendasar dalam peningkatan kesadaran hukum masyarakat. Pembangunan hukum lebih berorientasi pada masyarakat, yang tercermin melalui pengoptimalan keterlibatan masyarakat dalam rangkaian penyusunan Peraturan Daerah, di Aceh di kenal dengan Qanun. Ini perlu diyakini oleh aparatur Pemerintah baik Provinsi maupun Kabupaten/Kota sebagai strategi yang tepat untuk menggalang militansi kesadaran masyarakat terhadap ketaatan pelaksanaan ketentuan-ketentuan hukum.

Tulisan ini hendak menguraikan mengenai transformasi budaya dalam masyarakat Aceh pasca konflik, terutama dalam hal partisipasi publik untuk pembentukan kebijakan (Qanun Aceh maupun Kabupaten/kota) dan program mendorong wujudnya tata kelola pemerintahan yang baik dan bersih pada periode pembangunan perdamaian di Aceh.

\section{Pembahasan}

\section{A. Mekanisme Partisipasi Masyarakat}

Istilah partisipasi (participation) seringkali istilah tersebut diasumsikan hanya sebagai kontribusi financial, material, dan tenaga dalam suatu program. Kadang juga diberi pengertian sebagai self-help, self reliance, cooperation dan local autonomy dimana istilah-istilah tersebut kurang menggambarkan apa yang dimaksud dengan partisipasi itu sendiri. Self-help, self reliance dan local autonomy menggambarkan kondisi akhir yang diharapkan dari suatu program yang memakai pendekatan partisipatif. Cooperation menunjukkan cara bagaimana partisipasi masyarakat diimplementasikan pada suatu kegiatan atau program. ${ }^{4}$

Philipus M. Hadjon mengemukakan konsep partisipasi masyarakat berkaitan dengan konsep keterbukaan. Dalam artian, tanpa keterbukaan pemerintahan tidak mungkin masyarakat dapat melakukan peran serta dalam kegiatan-kegiatan pemerintah. Menurut Philipus M. Hadjon keterbukaan baik "openheid" maupun "openbaar-heid" sangat penting artinya bagi pelaksanaan pemerintah yang baik dan demokratis. Dengan demikian keterbukaan dipandang sebagai suatu asas ketatanegaraan mengenai pelaksanaan wewenang secara layak.

Konsep partisipasi terkait dengan konsep demokrasi, sebagaimana dikemukakan oleh Philipus M. Hadjon bahwa sekitar tahun 1960-an muncul suatu konsep demokrasi yang disebut demokrasi partisipasi. Dalam konsep ini rakyat mempunyai hak untuk ikut memutuskan dalam proses pengambilan keputusan pemerintahan. Dalam konsep demokrasi, asas keterbukaan datau partisipasi merupakan salah satu syarat minimum sebagaimana dikemukakan oleh Burkens dalam bukunya yang berjudul "Beginselen van de democratische reschsstaat" yang intinya.

1. pada dasarnya setiap orang mempunyai hak yang sama dalam pemilihan yang bebas dan rahasia;

Perguruan Tinggi Negeri dan Partai Politik Di Aceh - Tahun 2015, Komisi Informasi Aceh, Banda Aceh, hlm. 1

${ }^{4}$ Ariel R. Warouw, Tugas Dan Tanggung Jawab Masyarakat Dalam Pembentukan Perda, Lex Administratum, Vol. II/No.1/Jan - Mar/2014, hlm.7 
2. pada dasarnya setiap orang mempunyai hak untuk dipilih;

3. setiap orang mempunyai hak untuk dipilih;

4. badan perwakilan rakyat mempengaruhi pengambilan keputusan melalui sarana "mede beslissing-recht" (hak untuk ikut memutuskan dan atau melalui wewenang pengawas);

5. asas keterbukaan dalam pengambilan keputusan dan sifat keputusan yang terbuka;

6. dihormatinya hak-hak kaum minoritas.

Menurut Sad Dian Utomo mamfaat partisipasi masyarakat dalam pembuatan kebijakan publik, termasuk dalam pembuatan Perda adalah:

1) memberikan landasan yang lebih baik untuk pembuatan kebijakan publik

2) memastikan adanya implementasi yang lebih efektif karena warga mengetahui dan terlibat dalam pembuatan kebijakan publik

3) meningkatkan kepercayaan warga kepada eksekutif dan legislatif

4) efisiensi sumber daya, sebab dengan keterlibatan masyarakat dalam pembuatan kebijakan publik dan mengetahui kebijakan publik, maka sumber daya yang digunakan dalam sosialisasi kebijakan publik dapat dihemat. ${ }^{5}$

Dalam BAB VI Qanun Aceh Nomor 3 Tahun 2007 Pasal 23 dijelaskan bahwa berikut:

(1) Setiap tahapan penyiapan dan pembahasan qanun harus terjamin adanya ruang partisipasi publik.

(2) Masyarakat berhak memberikan masukan secara lisan atau tulisan dalam rangka penyiapan dan pembahasan rancangan Qanun.

(3) Masyarakat dalam memberikan masukan harus menyebutkan identitas secara lengkap

(4) Masukan sebagaimana dimaksud pada ayat (2) membuat pokok-pokok materi yang diusulkan

(5) Masukan dari masyarakat sebagimana dimaksud pada ayat (2) diagendakan dalam rapat penyiapan atau pembahasan rancangan qanun.

Mekanisme pelibatan dan partisipasi masyarakat dalam pelaksanaannya diatur sebagai berikut (Pasal 25 ayat (1)):

a. pada fase penyiapan prarancangan qanun oleh pemrakarsa pada masing-masing Satuan Kerja Perangkat Daerah sebagaimana dimaksud dalam Pasal 13 atau oleh Anggota/ Komisi/Gabungan Komisi/ Panitia Legislasi DPRA/DPRK sebagaimana dimaksud dalam Pasal 19;

b. pada fase pembahasan oleh Tim Asistensi yang dibentuk oleh Gubernur sebagaimana dimaksud dalam Pasal 16 dan Pasal 17 melalui forum rapat dengar pendapat;

c. pada fase pelaksanaan seminar akademik, sebagaimana dimaksud dalam Pasal 12;

d. pada fase pembahasan oleh DPRA/DPRK, sesuai dengan mekanisme yang ditetapkan dalam Tata Tertib DPRA/DPRK.

5 Ni Made Ari Yuliartini Griadi dan Agung Sri Utami, Partisipasi Masyarakat dalam Pembentukan Peraturan Daerah, Artikel Ilmiah : Kertha Patrika Vo.33 No.1, Januari 2008, hlm. 3. 
Lebih lanjut ayat (2) menjelaskan: mekanisme pelibatan dan partisipasi masyarakat sebagaimana dimaksud pada ayat (1) dapat dilakukan antara lain melalui Forum Seminar, Lokakarya, Fokus Grup Diskusi, Rapat Dengar Pendapat Umum (RDPU) dan bentukbentuk penjaringan aspirasi publik lainnya.

Mekanisme pelibatan dan partisipasi masyarakat sebagaimana dimaksud pada ayat (2) meliputi penyebaran draft pra rancangan qanun dan jadwal pembahasan kepada masyarakat.(Pasal 25 ayat (3) Qanun Aceh No.3 Tahun 2007). Masa partisipasi masyarakat ditetapkan dalam jadwal kegiatan pada setiap fase penyiapan dan pembahasan pra rancangan qanun/rancangan qanun (Pasal 25 ayat (4) Qanun Aceh No.3 Tahun 2007).

Masukan yang diberikan oleh masyarakat melalui mekanisme sebagaimana dimaksud dalam Pasal 23, Pasal 24 dan Pasal 25 paling lama 7 (tujuh) hari sejak dilakukan penyebarluasan sudah harus disampaikan kepada DPRA/DPRK atau Gubernur/Bupati/Walikota untuk menjadi bahan pertimbangan dalam penyempurnaan materi rancangan qanun (Pasal 26 Qanun Aceh No.3 Tahun 2007).

Pada prinsipnya, tidak ada perubahan tentang aturan pelibatan partisipasi publik antara Qanun Aceh No. 3 Tahun 2007 dengan Qanun Aceh No.5 Tahun 2011 tentang Tata Cara Pembentukan Qanun; Keterlibatan partisipasi masyarakat dalam pembentukan qanun ini sesuai dengan yang disebutkan oleh Friedrich Karl von Savigny yang menyatakan bahwa hukum itu tidak dibuat melainkan tumbuh dan berkembang bersama-sama dengan masyarakat. Hukum bukan merupakan konsep dalam masyarakat karena hukum tumbuh secara alamiah dalam pergaulan masyarakat yang mana hukum selalu berubah seiring perubahan social. ${ }^{6}$

Dalam teorinya, von Savigny mendefenisikan hukum "All Law is originally formed by custom and popular feeling, that is, by silently operating forces. Law is rooted in a people's history; that roots are ted by the consciousness, that faith and the custom of people." (keseluruhan hukum sungguh-sungguh terbentuk melalui kebiasaan dan perasaan kerakyatan, yaitu melalui pengoperasian kekusasaan secara diam-diam. Hukum berakar pada sejarah manusia, dimana akarnya dihiduplan oleh kesadaran, keyakinan, dan kebiasaan masyarakat). ${ }^{7}$

Didalam teori Sociological Jurisprudence oleh Ehrlich mengatakan bahwa "hukum (law) adalah lebih luas dari pada peraturan perundang-undangan (legal regulation). Negara hanyalah merupakan salah bentuk dari sekian banyak lembaga hukum (legal associations), sama halnya dengan lembaga lainnya. Pada dasarnya norma hukum selalu berasal dari fakta sosial yang dikendalikan oleh keyakinan rakyat (association of the people). Fakta-fakta hukum yang menjadi dasar segala hukum berupa kebiasaan, penguasa, pemilikan, dan pernyataan kehendak. Keempat macam fakta ini kadang-kadang memperkuat hubungan hukum. ${ }^{8}$

Sehingga hukum yang baik adalah hukum yang hidup dalam masyarakat (living law), dengan kata lain adalah pembentukan hukum tersebut haruslah dimulai dari bawah (buttom up) yaitu sesuai dengan aspirasi dari masyarakat melalui ruang partisipasi publik.

6 Walter Friedmann, Teori dan Filsafat Hukum: Idealisme Filosofis dan Problema Keadilan (Susunan II), (Jakarta: PT. Raja Grafindo Persada. 1994), hlm.1-61.

${ }^{7}$ Achmad Ali, Menguak Tabir Hukum, (Ghalia Bogor, cetakan kedua 2008), hlm. 23.

${ }^{8}$ Purnadi Purbacaraka dan M.Chaidir Ali, Disiplin Hukum,(Alumni Bandung, 1980), hlm. 50-51. 


\section{Fungsi Kekuasaan Legislatif}

Legislatif adalah struktur politik yang fungsinya membuat undang-undang. Di masa kini, lembaga tersebut disebut dengan Dewan Perwakilan Rakyat (Indonesia), House of Representative (Amerika Serikat), ataupun House of Common (Inggris). Lembaga-lembaga ini dipilih melalui mekanisme pemilihan umum yang diadakan secara periodik dan berasal dari partai-partai politik. Melalui apa yang dapat kami ikhtisarkan dari karya Michael G. Roskin, et.al, termaktub beberapa fungsi dari kekuasaan legislatif sebagai berikut : Lawmaking, Constituency Work, Supervision and Critism Government, Education, dan Representation. ${ }^{9}$

Constituency Work adalah fungsi badan legislatif untuk bekerja bagi para pemilihnya. Seorang anggota DPR/ legislatif biasanya mewakili antara $100.000 \mathrm{~s} / \mathrm{d}$ 400.000 orang di Indonesia. Tentu saja, orang yang terpilih tersebut mengemban amanat yang sedemikian besar dari sedemikian banyak orang. Sebab itu, penting bagi seorang anggota DPR untuk melaksanakan amanat, yang harus ia suarakan di setiap kesempatan saat ia bekerja sebagai anggota dewan.

Supervision and Criticism Government, berarti fungsi legislatif untuk mengawasi jalannya pelaksanaan undang-undang oleh presiden/perdana menteri, dan segera mengkritiknya jika terjadi ketidaksesuaian. Dalam menjalankan fungsi ini, DPR melakukannya melalui acara dengar pendapat, interpelasi, angket, maupun mengeluarkan mosi kepada presiden/perdana menteri.

Education, adalah fungsi DPR untuk memberikan pendidikan politik yang baik kepada masyarakat. Anggota DPR harus memberi contoh bahwa mereka adalah sekadar wakil rakyat yang harus menjaga amanat dari para pemilihnya. Mereka harus selalu memberi pemahaman kepada masyarakat mengenai bagaimana cara melaksanakan kehidupan bernegara yang baik. Sebab, hampir setiap saat media massa meliput tindaktanduk mereka, baik melalui layar televisi, surat kabar, ataupun internet.

Representation, merupakan fungsi dari anggota legislatif untuk mewakili pemilih. Seperti telah disebutkan, di Indonesia, seorang anggota dewan dipilih oleh sekitar 300.000 orang pemilih. Adapun ke-300.000 orang tersebut harus diwakili kepentingannya di dalam konteks negara. Ini didasarkan oleh konsep demokrasi perwakilan. Tidak bisa kita bayangkan jika konsep demokrasi langsung yang diterapkan, gedung DPR akan penuh sesak dengan 300.000 orang yang datang setiap hari ke Senayan. Bisa-bisa hancur gedung itu. Masalah yang muncul adalah, anggota dewan ini masih banyak yang kurang peka terhadap kepentingan para pemilihnya. Ini bisa kita lihat dari masih banyaknya demonstrasi-demonstrasi yang muncul di aneka isu politik. ${ }^{10}$

Dewan Perwakilan Rakyat Daerah (DPRD) sebagai organisasi publik, senantiasa mengalami dinamika dan perubahan yang diakibatkan oleh adanya perubahan lingkungan sehingga dalam organisasi perlu menyesuaikan dengan perubahan tersebut agar lebih efektif, efisien, kompetitif, adaptif dan responsibility dalam pencapaian tujuan. Mempertegas hal ini bahwa organisasi mengalami perubahan dalam rangka

\footnotetext{
${ }^{9}$ C.S. T Kansil dan S. T Kansil, Ilmu Negara, (Jakarta: Sinar Grafika, 2007), hlm. 159

${ }^{10}$ Miriam Budiardjo, Dasar-Dasar Ilmu Politik, (Jakarta: PT. Gramedia Pustaka Utama, 2008), hlm. 345- 348
} 
mencapai tujuan, bukan saja karena lingkungan dimana organisasi ini merupakan suatu keharusan agar organisasi dapat menyesuaikan permasalahan, tuntutan dan keinginan masyarakat. Perubahan tujuan ini akan menjadi pedoman, referensi dan sekaligus mengukur kinerja (performance) organisasi yang bersangkutan dalam melaksanakan tugas pokok dan fungsinya. Lebih lanjut, menegaskan bahwa didalam organisasi yang berusaha untuk menjadi lebih kompetitif, responsif dan adaptif, tujuan utama haruslah pada upaya mendorong semangat kerja sendiri diantara para kliennya atau di dalam masyarakat dimana ia saling berhubungan. ${ }^{11}$

\section{Fungsi Legislasi Dewan Perwakilan Rakyat Kabupaten (DPRK) Aceh Selatan}

Fungsi Legislasi merupakan fungsi dari DPRK untuk membentuk produk hukum yang bersifat mengatur (regeling), ini berkenaan dengan kewenangan untuk menentukan peraturan yang mengikat warga negara dengan norma-norma hukum yang mengikat dan membatasi. Berdasarkan ketentuan Pasal 1 angka 1 UU No 12 Tahun 2011 tentang Pembentukan Peraturan Perundang-Undangan, menyebutkan bahwa: "Pembentukan Peraturan Perundang-Undangan adalah Pembuatan Peraturan Perundang-Undangan yang mencakup tahapan Perencanaan, Penyusunan, Pembahasan, pengesahan atau Penetapan, dan Pengundangan. "12

Semua tahapan tersebut adalah prosedur baku yang harus dilewati dalam setiap pembentukan Peraturan Perundang-undangan termasuk pembentukan Peraturan Daerah (Qanun Kabupaten). Instrument Perencanaan Qanun Kabupaten dilakukan dalam Program Legislasi Daerah (Prolegda) yang disusun bersama antara DPRK dengan Pemerintah Daerah.

Secara umum yang di maksud dengan fungsi legislasi adalah fungsi untuk membuat Peraturan Daerah (Qanun). Hal ini di tegaskan pada Pasal 42 UndangUndang Nomor 32 Tahun 2004 yang menyatakan bahwa: DPRD (DPRK) mempunyai tugas dan wewenang membentuk peraturan daerah yang dibahas dengan Kepala Daerah untuk mendapat persetujuan bersama. DPRK membahas dan menyetujui Rancangan Peraturan Daerah tentang APBD bersama dengan Kepala Daerah.

Fungsi legislasi adalah suatu proses untuk mengakomodasi berbagai kepentingan para pihak pemangku kepentingan (stakeholders), untuk menetapkan bagai mana pembangunan daerah akan dilaksanakan. Oleh karena itu fungsi ini dapat mempengaruhi Karakter dan Profil Daerah melalui Peraturan Daerah sebagai produknya. Dengan demikian fungsi legislasi mempunyai arti yang sangat penting untuk menciptakan keadaan masyarakat yang diinginkan sebagai social engineering. Istilah Qanun yang berartikan peraturan, ini juga yang diterap masyarakat Aceh sebagai aturan daerah atau yang disebut dengan Perda (Pertaturan Daerah). Qanun ini merupakan payung hukum bagi masyarakat Provinsi Aceh terkhusus Kabupaten Aceh Selatan. Yang merancang atau merumuskan qanun ini adalah lembaga

\footnotetext{
${ }^{11}$ Syamsuddin Haris, Partai, Pemilu, dan Parlemen Era Reformasi (Jakarta: Yayasan Pustaka Obor Indonesia, 2014), hlm. 240

${ }^{12}$ Undang-Undang Nomor 12 Tahun 2011 tentang Pembentukan Peraturan Perundang-Undangan
} 
perwakilan rakyat, baik tingkat Provinsi maupun tingkat Kabupaten guna dan tujuan demi kedamaian, ketertiban, serta tercapainya kesejahteraan di daerah/wilayah tersebut. $^{13}$

\section{Bentuk dan Mekanisme Partisipasi Publik Dalam Penyusunan Kebijakan pada Dewan Perwakilan Rakyat Kabupaten (DPRK) Aceh Selatan periode 2014-2019}

Dalam rekam kinerjanya, DPRK Aceh Selatan periode 2014-2019 pada saat melaksanakan tugas legislatifnya mengacu pada program legislasi daerah (di Aceh disebut Rancangan Qanun/ Raqan), Raqan itu menjadi target kerja DPRK dalam menentukan prioritas regulasi yang akan dilahirkan.

Pada tahun 2015, terdapat 7 (tujuh) Rancangan Qanun yang telah dibahas bersama antara Eksekutif dan DPRK Aceh Selatan dan kemudian disahkan menjadi Qanun, yaitu:

1. Rancangan Qanun Tentang Pertanggungjawaban Pelaksanaan Anggaran Pendapatan dan Belanja Kabupaten Aceh Selatan Tahun Anggaran 2014, disahkan pada tanggal 22 September 2015;

2. Rancangan Qanun Tentang Perubahan Anggaran Pendapatan dan Belanja Kabupaten Aceh Selatan Tahun Anggaran 2015, disahkan pada tanggal 23 September 2015;

3. Rancangan Qanun Tentang Izin Usaha Perikanan, disahkan pada tanggal 26 November 2015;

4. Rancangan Qanun Tentang Pajak Hiburan, disahkan pada tanggal 27 November 2015;

5. Rancangan Qanun Tentang Perubahan Ketiga Atas Qanun Kabupaten Aceh Selatan Nomor 6 Tahun 2008 Tentang Susunan Organisasi dan Tata Kerja Lembaga Teknis Daerah Kabupaten Aceh Selatan, disahkan pada tanggal 28 November 2015;

6. Rancangan Qanun Tentang Perubahan Ketiga Atas Qanun Kabupaten Aceh Selatan Nomor 8 Tahun 2008 Tentang Pokok-Pokok Pengelolaan Keuangan Daerah, disahkan pada tanggal 29 November 2015;

7. Rancangan Qanun Tentang Anggaran Pendapatan dan Belanja Kabupaten Aceh Selatan Tahun Anggaran 2016, disahkan pada tanggal 26 November 2015;

Dari 7 (tujuh) Raqan yang kemudian disahkan menjadi Qanun Kabupaten Aceh Selatan Tahun 2015 itu, dari pengakuan responden bahwa sama sekali tidak ada ruang pelibatan publik dalam pembahasannya. Hal ini sebagaimana dijelaskan oleh Alja Yunadi, S.TP, bahwa ketika itu memang tidak ada dilakukan Rapat Dengar Pendapat Umum (RDPU) dalam proses penyusunan dari awal hingga ketok palu pengesahan Raqan menjadi Qanun. Menurut Alja Yunadi menyebutkan partisipasi publik dalam pembahasan qanun masih dipandang asing oleh sebahagian anggota DPRK ketika itu, karena rata-rata anggota DPRK periode ini sebahagian adalah orang-orang yang baru masuk parlemen dan diawal masa tugas belum begitu faham detil tupoksinya. Bahkan menurutnya pada awal tugas setelah pelantikan anggota DPRK Aceh Selatan pada tahun 2014, anggota

\footnotetext{
${ }^{13}$ Muhammad Zamzami dan Rosmala Dewi, Peran DPRK Aceh Selatan Dalam Pembuatan Qanun Kabupaten,http://ojs.uma.ac.id/index.php/publikauma, diakses pada tanggal diakses pada tanggal 19 September 2018.
} 
Badan Legislatif (Banleg) DPRK Aceh Selatan secara tiba-tiba akan mengesahkan beberapa Qanun tanpa pembahasan mendalam, konon lagi melibatkan partisipasi publik. Lalu Alja Yunadi, S.TP yang merupakan mantan aktifis Achehnese Civil Society Task Force (ACSTF) Banda Aceh bergerak dan mendorong penyusunan kebijakan yang berpihak kepada masyarakat di menghentikan aksi pengesahan Raqan menjadi Qanun secara tergesa-gesa itu dan menerangkan bahwa setiap penyusunan Rancagan Qanun harus sesuai tahapan dan prosesnya sesuai Qanun Aceh Nomor 3 Tahun 2007 Tentang Tata Cara Penyusunan Qanun (TCPQ). ${ }^{14}$

Hal senada juga dijelaskan oleh Hadi Surya, menjelaskan bahwa dengan beragamnya latar belakang anggota DPRK Aceh Selatan periode 2014-2019 menyebabkan tidak samanya persepsi dalam memahami tentang keterlibatan partisipasi publik dalam penyusunan kebijakan/ Qanun. Ia menyatakan pihaknya tidak ada melakukan Rapat Dengar Pendapat Umum pada tahun 2015 dalam menyusun dan mengesahkan 7 (tujuh) Qanun Kabupaten tersebut. Ia mengakui minimnya pelibatan publik melalui RDPU, hanya saja menurutnya cara menyiasati dengan menampung aspirasi masyarakat khususnya konsituen yang bersangkutan ketika masa reses dan turun ke masyarakat. Disitulah, wadahnya mencari masukan dari bawah untuk disuarakan pada saat pembahasan penyusunan kebijakan. ${ }^{15}$

Selanjutnya pada tahun 2016, terdapat 11 (sebelas) Rancangan Qanun yang telah dibahas bersama antara Eksekutif dan DPRK Aceh Selatan dan kemudian disahkan menjadi Qanun, yaitu:

1. Rancangan Qanun Tentang Tata Ruang Wilayah (RTRW) Kabupaten Aceh Selatan Tahun 2015-2035, disahkan pada tanggal 28 September 2016;

2. Rancangan Qanun Tentang Rencana Pembangunan Jangka Menengah (RPJM) Kabupaten Aceh Selatan Tahun 2013-2018, disahkan pada tanggal 28 September 2016;

3. Rancangan Qanun Tentang Bangunan Gedung, disahkan pada tanggal 28 September 2016;

4. Rancangan Qanun Tentang Pengelolaan Sampah, disahkan pada tanggal 28 September 2016;

5. Rancangan Qanun Tentang Pertanggungjawaban Pelaksanaan APBK Aceh Selatan Tahun Anggaran 2015, disahkan pada tanggal 21 Oktober 2016;

6. Rancangan Qanun Tentang Penambahan Penyertaan Modal Pemerintah Kabupaten Aceh Selatan Kepada PDAM Tirta Naga Tapaktuan, disahkan pada tanggal 21 Oktober 2016;

7. Rancangan Qanun Tentang Susunan Organisasi dan Tata Kerja Majelis Pendidikan Daerah Kabupaten Aceh Selatan, disahkan pada tanggal 21 Oktober 2016;

8. Rancangan Qanun Tentang Perubahan APBK Aceh Selatan Tahun Anggaran 2016, disahkan pada tanggal 10 November 2016;

9. Rancangan Qanun Tentang Pembentukan dan Susunan Perangkat Daerah Kabupaten Aceh Selatan, disahkan pada tanggal 15 November 2016;

10. Rancangan Qanun Tentang APBK Aceh Selatan Tahun Anggaran 2017, disahkan pada tanggal 30 November 2016;

\footnotetext{
${ }^{14}$ Alja Yunadi, Anggota DPRK Aceh Selatan, Wawancara, tanggal 26 Juli 2018.

${ }^{15}$ Hadi Surya, Anggota DPRK Aceh Selatan, Wawancara, tanggal 27 Juli 2018.
} 
11. Rancangan Qanun Tentang Perlindungan dan Pengelolaan Lingkungan Hidup, disahkan pada tanggal 20 Desember 2016.

Dari 11 (sebelas) Raqan yang kemudian disahkan menjadi Qanun itu, yang tercatat dalam Risalah dan Daftar Hadir di RDPU di Bagian Risalah Persidangan dan Hukum DPRK Aceh Selatan, pihak DPRK Aceh Selatan pernah melakukan 3 (tiga) kali RDPU dalam penyusunan Raqan yang berbeda (data terlampir), yaitu:

a. Rancangan Qanun Tentang Tata Ruang Wilayah (RTRW) Kabupaten Aceh Selatan Tahun 2015-2035, RDPU dilaksanakan pada tanggal 22 Agustus 2016;

b. Rancangan Qanun Tentang Rencana Pembangunan Jangka Menengah (RPJM) Kabupaten Aceh Selatan Tahun 2013-2018, RDPU dilaksanakan pada tanggal 23 Agustus 2016;

c. Rancangan Qanun Tentang Bangunan Gedung, RDPU dilaksanakan pada tanggal 24 Agustus 2016;

Pihak DPRK Aceh Selatan melakukan RDPU tersebut dengan mengundang pihakpihak terkait. Alja Yusnadi, yang ketika itu merupakan anggota Badan Legislasi (Banleg) menyatakan bahwa dikarenakan urgenitas dan supaya terciptanya kebijakan yang partisipatif maka dilaksanakan publik hearing (dengar pendapat publik). Dalam RDPU yang dilaksanakan tersebut banyak masukan dan saran-saran dari para peserta guna penyempurnaan Raqan yang sedang dibahas tersebut. ${ }^{16}$

Hal tersebut dibenarkan oleh Anhar, selaku Humas Sekretariat DPRK Aceh Selatan, ia menyatakan RDPU 3 (tiga) Raqan tersebut dilaksanakan dengan mengundang para stakeholder pihak legislatif, eksekutif, para camat, keuchik, dan perwakilan OKP/OMS seperti terlampir dalam daftar hadir RDPU. ${ }^{17}$

Senada dengan pendapat rekannya, Hadi Surya, menyatakan, seyogyanya memang setiap penyusunan Raqan menjadi Qanun harus semaksimal mungkin pelibatan partisipasi masyarakat guna partisipatif dan memiliki ruh suatu peraturan. Namun selama ini tidak semua Raqan dilakukan RDPU karena terkendala dana. Bahwa DPRK Aceh Selatan tidak memiliki pos khusus untuk anggaran RDPU, berbeda dengan pihak eksekutif yang memang memiliki anggaran untuk itu dan dilakukan dalam bentuk audiensi-audiensi dengan tenaga ahli dan masyarakat luas. ${ }^{18}$

Pada tahun 2017, terdapat 4 (empat) Rancangan Qanun yang telah dibahas bersama antara Eksekutif dan DPRK Aceh Selatan dan kemudian disahkan menjadi Qanun, yaitu:

1. Rancangan Qanun Tentang Hak Keuangan Dan Administratif Pimpinan Dan Anggota DPRK Aceh Selatan, disahkan pada tanggal 15 Agustus 2017;

2. Rancangan Qanun Tentang Pertanggungjawaban Pelaksanaan APBK Aceh Selatan Tahun Anggaran 2016, disahkan pada tanggal 18 September 2017;

3. Rancangan Qanun Tentang Perubahan APBK Aceh Selatan Tahun Anggaran 2017, disahkan pada tanggal 29 September 2017;

4. Rancangan Qanun Tentang APBK Aceh Selatan Tahun Anggaran 2018, disahkan

\footnotetext{
${ }^{16}$ Alja Yunadi, Anggota DPRK Aceh Selatan, Wawancara, tanggal 26 Juli 2018.

${ }^{17}$ Anhar, Kabag. Risalah Persidangan dan Hukum Sekretariat DPRK Aceh Selatan, Wawancara, tanggal 27 Juli 2018.

${ }^{18}$ Hadi Surya, Anggota DPRK Aceh Selatan, Wawancara, tanggal 27 Juli 2018.
} 
pada tanggal 30 November 2017.

Dari 4 (empat) Raqan yang kemudian disahkan menjadi Qanun Kabupaten Aceh Selatan Tahun 2017 itu, tidak ada pelibatan publik dalam pembahasannya. Hal ini sebagaimana dijelaskan oleh Alja Yunadi, bahwa ketika itu Raqan yang dibahas tidak menyangkut publik luas, seperti Raqan tentang Hak Keuangan dan Administratif Pimpinan dan Anggota DPRK Aceh Selatan hingga dalam pembahasannya tidak dilaksanakan RDPU. ${ }^{19}$

Rahimuddin selaku Kasie Risalah Persidangan menyatakan memang sepanjang tahun 2017 pihaknya tidak ada mencatat dan melaksanakan RDPU dalam pembahasan 4 (empat) Raqan menjadi Qanun. Hal itu diketahuinya benar karena jika ada pelaksanaan RDPU pihaknya merupakan pelaksana dan penyedia konsumsi dan honor peserta. ${ }^{20}$

Pada tahun 2018 ketika pengambilan data dan wawancara dilakukan pada bulan Juli 2018, DPRK Aceh Selatan belum ada mengesahkan satupun Raqan menjadi Qanun. Menurut informasi dari para responden bahwa pada tahun 2018 badan-badan dan alat kelengkapan DPRK Aceh Selatan baru saja dirombak dan belum bekerja maksimal, seperti misalnya Badan Legislasi (Banleg) dilakukan pergantian anggota-anggotanya.

Baik Alja Yusnadi maupun Hadi Surya menyatakan bahwa mereka memaksimalkan secara utuh menyerap aspirasi masyarakat/ konsituennya ketika melaksanakan reses dan turun ke lapangan, disitulah masyarakat bisa menyampaikan secara bebas pendapat dan saran-sarannya untuk ditampung dan diperjuangkan kemudiannya di gedung DPRK untuk memangkas jarak dan mengatasi kendala tidak adanya anggaran untuk dilakukannya RDPU dalam setiap penyusunan Qanun. Mereka sama-sama berpandangan bahwa sangat penting menggali keinginan dan pola buah pikir arus bawah (grassroot) dengan kesadaran bahwa peraturan yang baik adalah yang lahir dan mengakar dari bawah, bukan malah sebaliknya.

Dari semua Qanun yang telah disahkan DPRK Aceh Selatan periode 2014-2019, tercatat bahwa Raqan-raqan tersebut diinisiasi dan diprakarsai oleh pihak eksekutif Kabupaten Aceh Selatan. Ketika ditanyakan mengenai hak inisiatif anggota DPRK Aceh Selatan, Alja Yusnadi, S.TP menyatakan memang semua Raqan tersebut merupakan usulan dari pihak eksekutif yang kemudian dibawa dan dibahas bersama-sama dengan DPRK Aceh Selatan dan stakeholder. Ia mengakui memang hal itu merupakan suatu kekurangan yang tidak harus anggota DPRK Aceh Selatan periode ini, dengan latar belakang pendidikan dan pengalaman anggota DPRK Aceh Selatan yang beragam menyebabkan rendahnya kemampuan untuk memprakarsai Raqan. Namun menutupi hal itu, ketika Raqan usulan eksekutif disodorkan dan dilakukan pembahasan maka akan dilakukan pembahasan secara intens. Bahkan secara pribadi, ia dan rekan akan memprakarsai Raqan Tentang Hama Tanaman Pala dan diperjuangkan menjadi Raqan usulan DPRK Aceh Selatan karena dipandang hal tersebut riil dan menjadi masalah didalam masyarakat. Ide tersebut tercetus ketika ia menjaring aspirasi masyarakat dan selaku sarjana pertanian ia memang memandang hal itu urgen. Oleh karenanya ia

\footnotetext{
${ }^{19}$ Alja Yunadi, Anggota DPRK Aceh Selatan, Wawancara, tanggal 26 Juli 2018.

${ }^{20}$ Rahimuddin, Kasie. Risalah Persidangan Sekretariat DPRK Aceh Selatan, Wawancara, tanggal 27 Juli 2018.
} 
mengupayakan hal tersebut pada tahun 2018 ini masuk menjadi Raqan prioritas pembahasannya. $^{21}$

Dari hasil wawancara dengan para responden, memang terlihat masih rendahnya pelibatan dan keterlibatan publik (dalam hal ini masyarakat Aceh Selatan) dalam menyusun peraturan/ Qanun. Hal itu tentu saja akan mempengaruhi produk Qanun yang dilahirkan dan daya patuh masyarakat sebagai subjek hukum nantinya setelah Qanun yang berkaitan dengan masyarakat luas disahkan dan diberlakukan.

Selain itu dalam wawancara yang dilakukan oleh Muhammad Zamzami dan Rosmala Dewi $^{22}$ dalam tulisannya Peran DPRK Aceh Selatan Dalam Pembuatan Qanun Kabupaten, Anhar, selaku selaku HUMAS Sekretariat DPRK Aceh Selatan menyatakan tidak optimalnya peran legislasi DPRK Aceh Selatan yang dilaksanakan oleh Badan legislasi DPRK dalam setiap pembentukan Qanun Kabupaten dilakukan sesuai dengan mekanisme yang telah ditetapkan. Namun dalam pelaksanaan Badan Legislasi DPRK Aceh Selatan sering mengabaikan tahapan-tahapan pembentukan Qanun Kabupaten Aceh Selatan sesuai dengan Peraturan Pemerintah No 16 tahun 2010 dan Peraturan DPRK Aceh Selatan No 1 tahun 2010 terutama pada tahapan pembahasan Rancagan Qanun Kabupaten. Setiap Rancangan Qanun baik yang berasal dari DPRK maupun yang diusulkan oleh Pemerintah Kabupaten (Bupati) wajib dilakukan pembahasan antara DPRK dan Bupati atau Pemerintah Kabupaten, hal ini jelas di sebutkan dalam pasal 77 UU No 12 tahun 2011. Dari penjelasan tersebut tampak jelas tolak belakang dengan Rancangan Qanun Kabupaten yang diusulkan oleh Bupati Aceh Selatan disamping tidak dibahas secara maksimal juga ada yang tidak dibahas sama sekali, tetapi langsung disahkan pada saat penutupan Rapat Paripurna DPRK yang pengesahannya dibuat dalam bentuk berita acara persetujuan bersama antara Bupati Aceh Selatan dengan DPRK Aceh Selatan yang ditanda tangani oleh Bupati Aceh Selatan dan pimpinan DPRK Aceh Selatan. Seolah ketika sidang paripurna mengenai membahas tentang Rancangan Qanun, hal tersebut tidak dibahas hanya saja penyampaian Rancangan Qanun atau terkesan seolah pembacaan Rancangan Qanun saja dan tidak adanya pembahasan. Mengenai partispasi masyarakat memang seharusnya dilakukan dalam setiap penyusunan Raqan karena berdasarkan Pasal 96 Undang-Undang Nomor 12 Tahun 2011tentang Pembentukan Perundang- Undangan menyebutkan bahwa: Masyarakat berhak memberikan masukan secara lisan dan/atau tertulis dalam pembentukan Peraturan Perundang-Undangan (Qanun) Masyarakat secara lisan dan/atau tertulis sebagaimana di maksud pada Ayat (1) dapat dilakukan melalui: Rapat Dengar Pendapat Umum (RDPU), Kunjungan kerja, Sosialisasi, dan/ atau Seminar, lokakarya, dan/ atau diskusi. Masyarakat sebagaimana dimaksud pada Ayat (1) adalah orang perseorangan atau kelompok orang yang mempunyai kepentingan atas substansi rancangan Peraturan Perundang-Undagan (Qanun) Untuk memudahkan masyarakat dalam memberikan masukan secara lisan dan/atau tulisan sebagai mana dimaksud pada ayat (1) setiap rancangan Peraturan Perundang Undangan (qanun) harus dapat diakses

${ }^{21}$ Alja Yunadi, Anggota DPRK Aceh Selatan, Wawancara, tanggal 26 Juli 2018.

${ }^{22}$ Muhammad Zamzami dan Rosmala Dewi, Peran DPRK Aceh Selatan Dalam Pembuatan Qanun Kabupaten,http://ojs.uma.ac.id/index.php/publikauma, diakses pada tanggal diakses pada tanggal 19 September 2018. 
dengan mudah oleh masyarakat. Belum tingginya pemahan masyarakat Aceh Selatan mengenai Peraturan- Peraturan Daerah (Qanun) merupakan dampak dari lemahnya sistem penunjang penyosialisasiannya, baik itu yang bersifat formal maupun non formal. Misalnya: seminar, lokakarya, diskusi, media TV, media cetak, radio, spanduk. Hal tersebut tidak pernah dilihat, di dengar, dan dirasakan oleh masyarakat.

Dari ketentuan tersebut diatas, dalam pembahasan Rancangan Qanun Kabupaten, masyarakat perlu dilibatkan secara aktif setidaknya terdapat 2 (dua) alasan mengenai pelibatan partisipasi masyarakat yaitu: Masyarakat yang paling tahu kebutuhan pembangunan di daerahnya dan peraturanperaturan yang dibutuhkan yang menyangkut dangan kebutuhan kemasyarakatan itu sendiri. Mendorong masyarakat untuk melaksanakan dan mematuhi qanun Kabupaten tersebut dalam rangka efektifitas fungsi legislasi. Jadi secara umum partisipasi masyarakat secara aktif akan memperbesar tingkat efektifitas pelaksanaan Qanun Kabupaten, oleh karena itu DPRK harus membuka kesempatan kepada masyarakat atau para pihak lainnya untuk mengambil bagian (partisipasi) dalam seluruh tahapan pembentukan Qanun Kabupaten.

Dari uraian diatas jelaslah bahwa partisipasi masyarakat baik dalam memberikan masukan secara lisan maupun tertulis merupakan hak masyarakat dalam pembentukan Qanun Kabupaten, hal ini secara jelas diatur dalam Undang- Undang No 12 tahun 2011 dan pasal 22 Qanun Aceh No 5 tahun 2011 tentang tata cara pembentukan Qanun. Akan tetapi mekanisme tersebut selama ini tidak pernah dilaksanakan oleh Badan Legeslatif DPRK Aceh Selatan, artinya selama ini tidak pernah melibatkan partisipasi masyarakat baik sebelum pembahasan maupun pada saat pembahasan Rancangan Qanun bahkan pada saat penetapan Rancangan Qanun Kabupaten Aceh Selatan.

Anhar, ${ }^{23}$ juga menyebutkan bahwasanya salah satu hambatan yang dihadapi anggota DPRK Aceh Selatan dalam proses pembentukan Qanun Kabupaten yaitu minimnya SDM anggota DPRK itu sendiri. Hal tersebut di sebabkan oleh beberapa faktor, diantaranya:

a. Rendahnya jenjang pendidikan anggota DPRK tersebut.

b. Dari tiga puluh (30) orang anggota DPRK Aceh Selatan, hanya Sembilan (9) orang

a. yang bergelar Strata satu (sarjana).

b. Kurang berpengalamannya anggota DPRK Aceh Selatan dalam proses pembuatan Qanun Kabupaten.

c. Kurang pahamnya anggota DPRK Aceh Selatan dalam pembuatan (Qanun).

d. Sedikitnya tenaga ahli yang dipekerjakan di DPRK Aceh Selatan.

e. Kurang mengertinya anggota DPRK Aceh Selatan atas kebutuhan hukum yang dibutuhkan oleh masyarakat Kabupaten Aceh Selatan itu sendiri.

Dengan belum optimalnya pelibatan publik (dalam hal ini masyarakat Aceh Selatan) dalam penyusunan kebijakan/ Qanun Kabupaten, tentu sangat disayangkan dan merupakan sebuah kerugian yang besar bagi masyarakat di daerah tersebut yang bahwa hak partispasi masyarakat dalam penyusunan Qanun telah dijamin oleh sejumlah undangundang dan Qanun Aceh tentang Tata Cara Pembuatan Qanun. Dengan absennya

\footnotetext{
${ }^{23}$ Muh. Ammad Zamzami dan Rosmala Dewi, Peran DPRK Aceh Selatan Dalam Pembuatan Qanun Kabupaten,http://ojs.uma.ac.id/index.php/publikauma, diakses pada tanggal diakses pada tanggal 19 September 2018
} 
partispasi masyarakat dalam penyusunan Qanun (terutama yang bersinggungan langsung dengan masyarakat luas) bisa saja menyebabkan lahirnya kebijakan yang tidak partispatif dan merugikan/ memberatkan masyarakat daerah dimaksud.

Oleh karenanya mengingat pentingnya kebijakan yang mewakili suara akar rumput (grassroot), sudah seyogyanya DPRK Aceh Selatan lebih terbuka dan dengan upaya yang maksimal melibatkan masyarakat dalam pembuatan Qanun sejak dari tahap perencanaan, pembahasan hingga pengesahan suatu Qanun guna tumbuhnya nilai kepatuhan hukum dan rasa memiliki ditengah masyarakat karena suara yang disampaikannya ditampung dan dituangkan dalam bentuk kebijakan partispatif. Dan pihak DPRK Aceh Selatan agar tidak mempersempit makna partisipasi masyarakat hanya pada pelibatan tahap Rapat Dengar Pendapat Umum (RDPU. Pihak DPRK Aceh Selatan harus membuka ruang seluas-luasnya guna tersalurnya aspirasi masyarakat, bisa dalam bentuk hearing, dialog pada saat reses, workshop dan konsultasi. Kesemua itu dengan tujuan terjaminnya saran, ide dan masukan masyarakat terwakili secara proporsional oleh DPRK Aceh Selatan selaku perpanjangan dan mewakili rakyat.

Demikian juga masyakarat/ organisasi kemasyarakat agar terus pro aktif terlibat dalam penyusunan kebijakan dan menyampaikan aspirasinya kepada DPRK Aceh Selatan selaku perwakilannya guna terciptanya kebijakan yang memuat kebutuhan dan keinginan bersama masyarakat Aceh Selatan secara keseluruhan.

\section{Penutup}

\section{Kesimpulan}

Dari uraian di atas dapat ditarik beberapa kesimpulan penting antara lain:

Ruang partisipasi masyarakat sangat berguna demi terciptanya efektifitas terhadap pemberlakuan qanun dan kebijakan yang berpihak kepada kepentingan publik. DPRK Aceh Selatan masih sangat minim melibatkan masyarakat dalam penyusunan kebijakan/ Qanun dengan alasan keterbatasan dana. Selayaknya DPRK Aceh Selatan harus mengupayakan secara optimal pelibatan masyarakat dalam penyusunan suatu Qanun, tidak hanya dalam bentuk RDPU tetapi dengan menggunakan segala isntrumen dan saluran seperti yang telah disediakan oleh undang-undang dan Qanun Aceh tentang Tata Cara Pembuatan Qanun.

Ada kesan DPRK Aceh Selatan masih tidak terlalu serius tentang pelibatan masyarakat dalam penyusunan Qanun, hal itu terlihat dengan tidak adanya upaya maksimal dan masif dari DPRK Aceh Selatan untuk menjaring aspirasi masyarakat dalam penyusunan kebijakan. Rendahnya pelibatan publik merupakan awaal lahirnya kebijakan yang tidak partisipatif.

\section{Saran}

Dewan Perwakilan Rakyat Kabupaten (DPRK) Aceh Selatan dan Pemerintah Kabupaten Aceh Selatan diharapkan senantiasa membuka ruang partisipasi masyarakat terhadap pembentukan qanun guna terciptanya efektifitas pemberlakuan qanun dan kebijakan yang berpihak kepada kepentingan publik di Kabupaten Aceh Selatan. Pihakpihak LSM dan organisasi kemasyarakatan lainnya perlu mendorong pemerintah 
sekaligus memberikan pencerahan kepada masyarakat agar setiap pembentukan kebijakan pemerintah yang bersifat Regeling senatiasa dilibatkan masyarakat yang bersentuhan langsung dengan qanun yang akan di berlakukan.

\section{Daftar Pustaka}

Ali, Achmad, Menguak Tabir Hukum, cetakan kedua, Ghalia, Bogor, 2008

Anonimous, Laporan Evaluasi Badan Publik Tahun 2015: Laporan Evaluasi Implementasi Keterbukaan Informasi Publik pada Satuan Kerja Perangkat Aceh, Pemerintah Kabupaten/Kota, Perguruan Tinggi Negeri dan Partai Politik Di Aceh - Tahun 2015, Komisi Informasi Aceh, Banda Aceh

Budiardjo, Miriam, Dasar-Dasar Ilmu Politik, Jakarta: PT. Gramedia Pustaka Utama, 2008

Friedmann, Walter, Teori dan Filsafat Hukum: Idealisme Filosofis dan Problema Keadilan (Susunan II), Jakarta: PT. Raja Grafindo Persada. 1994

Haris, Syamsuddin, Partai, Pemilu, dan Parlemen Era Reformasi Jakarta: Yayasan Pustaka Obor Indonesia, 2014

Kansil C.S. T, dan S. T Kansil, Ilmu Negara, Jakarta: Sinar Grafika, 2007

Made Ari Yuliartini Griadi, Ni dan Agung Sri Utami, Partisipasi Masyarakat dalam Pembentukan Peraturan Daerah, Artikel Ilmiah: Kertha Patrika Vo.33 No.1, Januari 2008

Purbacaraka, Purnadi dan M.Chaidir Ali, Disiplin Hukum,Alumni Bandung, 1980

Siddiq Armia, Muhammad, Eksekutif Review Terhadap Perda Retribusi Di Daerah Otonomi Khusus, Jurnal Rechtsvinding - Media Pembinaan Hukum Nasional, Vol. 5, No. 2, 2016

Ulya, Zaki, Refleksi Memorandum of Understanding (MoU) Helsinki Dalam Kaitan Makna Otonomi Khusus Di Aceh, Jurnal Konstitusi, Vol. 11, No. 2, 2014

Warouw, Ariel R., Tugas Dan Tanggung Jawab Masyarakat Dalam Pembentukan Perda, Lex Administratum, Vol. II/No.1/Jan - Mar/2014

Zamzami, Muhammad dan Rosmala Dewi, Peran DPRK Aceh Selatan Dalam Pembuatan Qanun Kabupaten, http://ojs.uma.ac.id/index.php/publikauma, diakses pada tanggal diakses pada tanggal 19 September 2018 
Volume 14, Nomor 1, Januari-Juni 2019

Undang-Undang Nomor 12 Tahun 2011 tentang Pembentukan Peraturan PerundangUndangan

Undang-Undang Nomor 11 Tahun 2006 tentang Pemerintahan Aceh

Undang-Undang Nomor 23 Tahun 2014 tentang Pemerintahan Daerah

Pemendagri Nomor 169 Tahun 2004 Tentang Pedoman Prolega

Qanun Aceh Nomor 3 Tahun 2007 tentang Tata Cara Pembentukan Qanun

Qanun Aceh Nomor 5 Tahun 2011 tentang Tata Cara Pembentukan Qanun 